\title{
ISSN 2656-4807 \\ KEDUDUKAN ANAK NON MUSLIM TERHADAP HARTA WARISAN DITINJAU DARI KOMPILASI HUKUM ISLAM
}

\author{
Nizmah \\ Fakultas Ekonomi Universitas Surapati Jakarta \\ nizmah_nina@yahoo.com
}

\section{ABSTRACT}

The noble Qur'an has explained the laws of inheritance, the conditions of each heir with a sufficient explanation, where no one among humans escapes the inheritance or inheritance. Because the Qur'an is the backing in establishing the law and the extent of its parts. And very few are determined based on Sunnah or ijma. there is no position of nonMuslim children on inheritance in compilation of Islamic law. While the Religious Court is a court that has the authority to examine and try inheritance disputes for people who are Muslim. Thus, if there is a dispute over inheritance issues between children of Muslims and non-Muslims, it must be resolved through the Religious Courts. Formulation of the problem in this study is how the position of non-Muslim children on the inheritance of Islamic heirs is reviewed from the Compilation of Islamic Law. with literature analysis it means that the author takes data based on existing literature.

Based on the results of the study, according to the Compilation of Islamic Law dividing inheritance to the entitled heirs is the obligation of heirs to the heir to be implemented after the heirs have carried out other obligations as contained in. The position of nonMuslim children on the inheritance of Islamic heirs based on Islamic law does not obtain inheritance from the inheritance of their parents. According to the Compilation of Islamic Law as in the case of the Religious Court, it shows that the position of non-Islamic children on inheritance from the inheritance of the property of their parents does not receive the right inheritance, but based on the Religious High Court, get a section called "Wasiah Wajibah"

\section{Keywords ; child position, inheritance, compilation of Islamic law}

\section{ABSTRAK}

Al-Qur'an yang mulia telah menerangkan hukum-hukum kewarisan, keadaankeadaan setiap ahli waris dengan penjelasan yang cukup memadai, dimana tidak seorangpun diantara manusia yang luput dari bagian atau batasan warisan. Sebab Alquranlah sandarannya di daalam menetapkan hukum dan kadar bagiannya. Dan sangat sedikit sekali yang ditetapkan berdasarkan Sunnah atau ijma. kedudukan anak non 


\section{AS-SYAR'I: Jurnal Bimbingan \& Konseling Keluarga}

muslimterhadap harta warisan dalam kompilasi hukum Islam tidak ada. Sementara Pengadilan Agama adalah pengadilan yang berwenang untuk memeriksa dan mengadili sengketa kewarisan bagi orang yang beragama Islam. Dengan demikian jika terjadi sengketa masalah warisan antara anak orang-orang yang beragama Islam dengan non muslim maka harus diselesaikan melalui Pengadilan Agama.Rumusan Masalah dalam penelitian ini adalah Bagaimana kedudukan anak non muslim terhadap harta warisan pewaris Islam ditinjau dari Kompilasi Hukum Islam, Penelitian ini dilakukan dengan analisa literature artinya penulis mengambil data berdasarkan literature yang ada.

Berdasarkan hasil penelitian maka Menurut Kompilasi Hukum Islam membagi harta warisan kepada para ahli waris yang berhak merupakan kewajiban ahli waris kepada pewaris untuk dilaksanakan setelah ahli waris telah melaksanakan kewajiban yang lain sebagaimana yang terdapat dalam. Kedudukan anak non muslim terhadap harta warisan pewaris Islam berdasarkan hukum Islam tidak mendapatkan harta warisan dari harta peninggalan orang tuanya. Menurut Kompilasi Hukum Islam sebagaimana pada kasus Pengadilan Agama menunjukkan bahwa kedudukan anak non Islam terhadap harta warisan dari peninggalan harta kedua orang tuanya tidak mendapatkan warisan sebagainya mestinya, namun berdasarkan Pengadilan Tinggi Agama mendapatkan bagian yang disebut dengan "Wasiat Wajibah".

\section{Kata kunci ; kedudukan anak, Harta warisan, kompilasi hokum islam}

\section{PENDAHULUAN}

Syariat Islam telah menetapkan hak dan kewajiban ahli waris memperoleh hak untuk mewarisisesuai dengan ketentuan Hukum Islam.Islam mengakui ahli waris mewarisi laki atau perempuan melalui jalan yang dibenarkan Syariat Islam.Selanjutnya Syariat Islam mengakui berpindahnya harta waris dari pewaris kepada ahli waris tanpa diskriminasi.Muhammad Ali Ash Shabuniy mengatakan bahwa :

Al-Qur'anyang mulia telah menerangkan hukum kewarisan, keadaan setiap ahli waris dengan penjelasan yang cukup memadai, dimana tidak seorangpun diantara manusia yang luput dari bagian atau batasan warisan. Sebab Al-quranlah sandarannya di daalam menetapkan hukum dan kadar bagiannya. Dan sangat sedikit sekali yang ditetapkan berdasarkan Sunnah atau ijma'.15

Dengan demikian hukum kewarisan Islam pada dasarnyaa bersumber kepada beberapa ayat Al-quran sebagai Firman Allah yang diturunkan kepada Nabi Besar Muhaammad SAW dan Hadist Rasululullah Saw, yang terdiri dari ucapan, perbuatan, dan hal-hal yang didiamkan Rasulullah. Di dalam Al-quran maupun hadis dasar hukum kewarisan disebutkan secara tegas dan ada yang secara tersirat, bahkan kadang-kadang

\footnotetext{
${ }^{15}$ Muhammad Ali Ash Shabuniy., Hukum Waris Islam, Al-Ikhlas, Surabaya, 1991,
} hal.45. 


\section{AS-SYAR'I: Jurnal Bimbingan \& Konseling Keluarga}

hanya berisi pokok-pokoknya saja, yang paling banyak ditemui dasar atau sumber hukum kewarisan itu dalam surat An-Nisa' ayat 7 menyatakan :

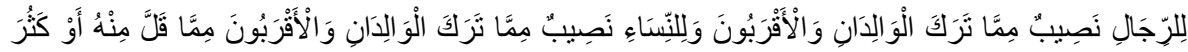

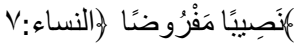

Artinya :

"Untuk laki-laki ada bagian dari peninggalan Ibu Bapaknya dan karib-karib yang terdekat, dan untuk perempuan-perempuan ada bagian pula dari peninggalan harta ibu Bapak dan karib yang terdekat, baik sedikit ataupun banyak sebagaimana yang telah ditetapkan"2

Di dalam Al-Quran mensyaratkan sebab-sebab seorang berhak mewarisi yaitu :

- Kekerabatan sesungguhnya yakni hubungan nasab.

- Pernikahan yaitu ijab kabul yang sah yang terjadi diantara suami isteri.

- Perbudakan yaitu kekerabatan berdasarkan hukum yang disebut 'walaulitqi' atau "Walaun Ni'mati". ${ }^{3}$

Setelah diketahui sebab-sebab seseorang mewaris dalam harta peninggalan maka hak Islam tidak menyinggung tentang seseorang yang murtad dan ahli waris non muslim merupakan salah satu penghalang seseorang untuk menerima warisan. Hal ini sesuai dengan yang dikatakan Ramulyo dalam sejarah Rasulullah yang menyebutkan : "bahwa tidak ada hak waris bagi anak laki-laki yang murtad atau non muslim".4

Budiarto menyatakan bahwa : Anak kandung yang beragama non Islam status hukumnya bukan Ahli Waris, namun ia berhak mendapat bagian dari harta warisan dari kedua orang tuanya berdasarkan "Wasiat Wajibah" yang bagiannya sama dengan bagian anak peerempuan ahli waris"5

\section{METODE PENELITIAN}

Di dalam melengkapi penyusunan penelitian ini, penulis melakukan:

1. Penelitian Kepustakaan (Library Research)

Dalam penulisan penelitian ini penulis mengumpulkan bahan-bahan berupa peraturan perundang-undangan maupun buku wajib yang ada kaitannya dengan penulisan penelitian ini.

2. Penelitian Lapangan (Field Research)

Pengambilan data dalam penyusunan penelitian ini menggunakan metode

${ }^{2}$ Departemen Agama RI, Al-Qur'an dan Terjemahannya, Bumi Restu, Jakarta, 1996, hlm. 71

${ }^{3}$ Ibid.,hal.55

${ }^{4}$ M. Idris Ramulyo., Perbandingan Pelaksanaan Hukum Kewarisan Islam Dengan Kewarisan Menurut Hukum Perdata, Sinar Grafika, Jakarta, 1994, hal.111.

${ }^{5}$ Budiarto, Harta Warisan Pewaris Islam non Muslim, Rineka Cipta, Jakarta, 2001, hlm.107. 


\section{AS-SYAR'I: Jurnal Bimbingan \& Konseling Keluarga}

deduksi yang artinya penulis memulai dari sesuatu pengetahuan yang bersifat umum dan selanjutnya hendak menilai sesuatu kejadian yang khusus. Oleh karena itu dalam penyusunan penelitian ini sengaja diberi batasan, dengan demikian penulis hanya menyajikan segala sesuatu yang dirasakan, dilihat dan yang penulis dengan selama di lapangan yang berkisar pada permasalahan tersebut diatas dan untuk memudahkan penulis memahami permasalahannya.

\section{HASIL DAN PEMBAHASAN}

Warisan berasal dari kata waris, yang berasal dari bahasan Arab, yaitu warith, yang dalam bahasa Indonesia berarti ahli waris, yaitu orang yang berhak mewarisi dan pihak lain ada yang menamakannya "Hukum Waris" atau "Hukum Pusaka", dan lain-lain. ${ }^{10}$

Menyatakan bahwa Pasal 171 huruf a Kompilasi Hukum Islam "Kewarisan adalah : hukum yang mengatur tentang perpindahan hak kepemilikan harta peninggalan (tirkah) pewaris, menentukan siapa-siapa yang berhak dan masing-masing."12

Ahli waris ada 2 (dua) macam, pertama, ahli waris nasabiyah yaitu ahli waris yang berhubungan kewarisannya didasarkan karena hubungan darah (kekerabatan) kedua ahli waris sababiyah yaitu ahli waris yang hubungan kewarisannya karena suatu sebab, yaitu sebab pernikahan dan kemerdekaan budak atau menurut sebagian mazhab hanafiah, karena sebab perjanjian (janji setia), sebab perjanjian ini kurang populer di Indonesia karena ummat Islam di Indonesia menganut mazhab safii. sumber hukum kewarisan itu dalam surat An-Nisa' ayat 7 yang artinya :

"Bagi orang laki-laki ada hak bagian dari harta peninggalan ibu bapaknya dan kerabatnya dan bagi orang wanita ada hak bagian (pula) dari harta peninggalan ibu bapak dan kerabatnya, baik sedikit ataupun banyak menurut bagian yang telah ditetapkan"14

Pengertian besar kecilnya hak waris dalam keluarga dilihat dari beberapa segi yaitu

1. Dekat atau jauhnya hubungan seseorang dengan yang mati.

2. Besarnya jasa terhadap yang mati.

3. Jenis kelamin, laki-laki atau wanita.

Dalam Kompilasi Hukum Islam pada Pasal 171 huruf a disebutkan : "Hukum waris adalah hukum yang mengatur tentang pemindahan hak pemilikan harta peninggalan (tirkah) pewaris, menentukan siapa-siapa yang berhak menjadi ahli waris dan berapa

${ }^{10}$ Hazirin., Hukum Kekeluargaan Nasional, Tinta Mas, Jakarta,1982, hlm,29

${ }^{12}$ Ahmad Rofiq, Hukum Islam Di Indonesia, PT. Raja Grafindo Persada, Jakarta, 1998, hlm. 355

14 Departemen Agama RI, Al-Qur'an dan Terjemahannya, Bumi Restu, Jakarta, 1996,hlm.71 


\section{AS-SYAR'I: Jurnal Bimbingan \& Konseling Keluarga}

bagiannya masing-masing. ${ }^{19}$

"Hukum kewarisan, sering dikenal dengan istilah faraidh, bentuk jamak dari kata tunggal faraidh, artinya ketentuan. Hal ini karena dalam Islam bagian-bagian yang menjadi hak ahli waris telah dibakukan dalam Al-Qur'an".20

Dengan demikian dalam hukum waris (faraid) ada tiga unsur yang terdapat didalam pelaksanaannya, yaitu :

1. Orang yang meninggal dunia atau pewaris (muwarits).

2. Harta warisan atau tirkah (mauruts)

3. Ahli waris (Warits). ${ }^{22}$

Harta warisan atau tirkah (mauruts).

Pasal 171 hurufd Kompilasi Hukum Islam menyebutkan bahwa harta peninggalan adalah harta yang ditinggalkan oleh pewaris baik yang berupa harta benda miliknya maupun hak-haknya ${ }^{24}$.

Ahli Waris (warits).

Ahli waris (warits) merupakan orang yang berhak untuk menerima hak dan kewajiban si pewaris. Salah satu yang terpenting dalam mempelajari hukum waris Islam adalah menyangkut 'waris', kalau ditinjau dari segi asal kata, perkataan waris berasal dari bahasa Arab yaitu "warits", secara gramatikal berarti 'yang tinggal atau yang kekal', maka dengan demikian apabila dihubungkan dengan persoalan hukum waris, perkataan warits tersebut berarti orang-orang yang berhak untuk menerima pusaka dari harta yang ditingggalkan oleh si mati dan populer di istilahkan dengan 'ahli waris'. ${ }^{25}$

Ada beberapa sebab seseorang tersebut dapat berkedudukan sebagai ahli waris oleh sebab perkawinan. Timbulnya kewarisan oleh karena adanya perkawinan ini adalah perkawinan yang sah menurut Syariat Islam, perkawinan tersebut sahapabila memenuhi apa yang menjadi rukun nikah dalam perkawinan. Adapun yang menjadi rukun nikah tersebut adalah :

a. Sighat ('akad) yaitu perkataan dari pihak wali perempuan.

b. Wali si perempuan/mewakilinya.

c. Adanya calon mempelai wanita.

d. Adanya calon mempelai laki-laki

e. Adanya dua orang yang berkedudukan sebagai saksi dalam nikah itu.

19 M. Munir, Kompilasi Hukum Islam Di Indonesia, Humaniora,Bandung, 1992, hlm.73.

${ }^{20}$ Ahmad Rafiq., Hukum Islam Di Indonesia, PT. Raja Grafindo Persada, Jakarta, 1995, hlm.356.

${ }^{22}$ Ibid.,hlm. 30.

${ }^{24} \mathrm{M}$. Idris Ramulyo., Op-Cit, hlm. 102

${ }^{25}$ Suhrawardi K Lubis., Hukum Waris Islam, Sinar Grafika, Jakarta, 1995, hlm.52. 


\section{AS-SYAR'I: Jurnal Bimbingan \& Konseling Keluarga}

Dengan demikian seorang yang berkedudukan sebagai ahli waris disebabkan oleh karena adanya hubungan wala' dengan pewaris tidak lagi kita jumpai. Sehingga pada saat ini yang umum kita jumpai seseorang dapat berkedudukan sebagai ahli waris disebabkan oleh karena adanya sebab perkawinan dan kekerabatan (nasab).

Ada tiga golongan ahli waris menurut ajaran kewarisan bilateral yaitu:

1. Dzul Faraa-idh

2. Dzul qarabat

3. Mawali. ${ }^{26}$

Hak dan Kwajiban Ahli Waris Sebagaimana yang telah disebutkan, bahwa timbulnya sesuatu hak akan pula menimbulkan suatu kewajiban. Dalam hukum waris Islam kewajiban yang timbul tersebut berkaitan dengan kewajiban ahli waris kepada pewarisnya. Ada beberapa hal yang merupakan kewajiban ahli waris kepada pewarisnya. Hal ini dapat dilihat dalam Pasal 175 ayat 1 Kompilasi Hukum Islam menyebutkan :

1. Kewajiban ahli waris terhadap pewaris adalah :

a. Mengurus dan menyelesaikan sampai pemakaman jenazah selesai.

b. Menyelesaikan baik hutang-hutang berupa pengobatan, perawatan termasuk kewajiban pewaris maupun menagih piutang.

c. Menyelesaikan wasiat pewaris.

d. Membagi harta warisan diantara ahli waris yang berhak.

Dalam Kompilasi Hukum Islam memberi pengertian tentang wasiat sebagai berikut: wasiat merupakan pemberian suatu benda dari pewaris kepada orang lain atau lembaga yang akan berlaku setelah pewaris meninggal dunia (Pasal 171 huruf f Kompilasi Hukum Islam). Dikarenakan wasiat ini dilaksanakan atau diberikan kepada si penerima wasiat setelah pemberi wasiat meninggal dunia, maka pelaksanaannya dilakukan oleh ahli waris dan hal ini menjadi kewajiban ahli waris kepada pewaris untuk melaksanakannya. ${ }^{31}$

\section{Larangan Hak Mewarisi Menurut Hukum Islam}

Dalam hukum waris Islam ada hal-hal yang menyebabkan seseorang terhalang untuk menerima harta warisan dari si pewaris. Halangan-halangan mewaris adalah sifat-sifat yang mengakibatkan terhalangnya pewaris untuk mewaris yaitu :

1. Perbudakan.

Budak yang dikuasai seseorang tidak dapat mewaris harta kerabatnya, karena apabila ia mewaris sesuatu akan diambil tuannya. Padahal tuannya itu adalah orang lain bukan kerabat budak tersebut. Cukup poluler pernyataan para ahli hukum Islam yang menyatakan bahwa budak dan apa saja yang

\footnotetext{
${ }^{26}$ Ibid., hlm.72

${ }^{31}$ lbid, hlm. 108
} 


\section{AS-SYAR'I: Jurnal Bimbingan \& Konseling Keluarga}

dimiliki adalah menjadi milik tuannya. Jika demikian maka ia tidak boleh mewaris agar hartanya itu tidak berpindah kepada tuannya.

Pada surat Al-quran surat An Nahl ayat (75) yang Artinya :

"Hamba yang dimiliki atau hamba yang mempunyai harta benda tidak mempunyai kekuasaan atas sesuatu apapun juga"35.

2. Pembunuhan.

Apabila penerima waris membunuh pewaris maka ia tidak boleh mewaris hartanya, hal ini sesuai dengan sabda Rasulullah yang artinya :

"Dari Abu Hurairah menyampaikan sabda Rasulullah SAW bahwa "si pembunuh tidak mewarisi dari pewaris yang dibunuh (HR.Nasai)" 36

Pada dasarnya pembunuhan itu adalah merupakan tindakan pidana kejahatan, namun dalam beberap hal tertentu pembunuhan tersebut tidak dipandang sebagai dosa.

a. Pembunuhan secara hak dan tidak melawan hukum seperti :

1) Pembunuhan di medan perang

2) Melaksanakan hukuman mati

3) Membela jiwa, harta dan kehormatan

b. Pembunuhan secara tidak melawan hak dan melawan hukum (tindak pidana kejahatan), sperti :

1) Pembunuhan dengan sengaja

2) Pembunuhan yang tidak sengaja

3. Karena Murtad

Orang yang keluar dari agama Islam disebut Murtad, orang murtad dalam kompilasi hukum Islam tidak mendapat harta warisan. Lebih tegas dikatakan bahwa :"Orang yang keluar dari agama Islam tidak mendapat pusaka dari keluarganya yang maish tetap memeluk agama Islam dan sebaliknya iapun tidak mempusakai mereka yang masih beragama Islam"37

Lebih tegas juga ditegaskan di dalam Hadis Rasulullah yang Artinya :

"Dari Abu Bardah Ia berkata: Rasulullah Saw bersabda, telah mengutusku untuk menemui seorang laki-laki yang kawin dengan istri bapaknya, Nabi Saw menyuruh supaya aku membunuh laki-laki tersebut dan membagi hartanya sebagai harta rampasan, sedangkan laki-laki tersebut murtad"38

4. Kafir (Non Muslim)

Orang yang tidak memeluk agama Islam (kafir) tidak berhak menerima

\footnotetext{
${ }^{35}$ Departemen Agama RI, Op-Cit, hlm.248

${ }^{36}$ Badrul Aini., Syarah Shahih Bukhari, Abdus Salam, Mesir, t.t, hlm.112.

${ }^{37}$ Sulaiman Rasyid, Fiqh Islam, Sinar Baru, Jakarta, 2007, hlm.351.

${ }^{38}$ Badrul Aini., Op-Cit, hlm.142
} 


\section{AS-SYAR'I: Jurnal Bimbingan \& Konseling Keluarga}

pusaka dari keluarganya yang memeluk agama Islam"39. Begitu juga sebaliknya, orang Islam tidak berhak pula menerima pusaka dari keluarganya yang kafir, hal ini sesuai dengan Sabda Rasulullah Saw yang Artinya:

"Orang Islam tidak mewarisi orang kafir, dan orang kafir tidak pula mewarisi orang Islam” (HR.Jama'ah). ${ }^{40}$

\section{Kedudukan Anak Non Muslim terhadap Harta Warisan}

Fazlur Rahman, menyatakan bahwa Al-Qur'an merupakandokumen yang diperuntukan umat manusia, bahkan di dal beberapa kali menegaskan bahwa kitab ini merupakan petunjuk bagi umat manusia. ${ }^{41}$ Semenjak keturunannya, Rasulullah merupakan pemegang otoritas sebagai penafsir terhadap Al-Qur'an. Kelebihannya beliau adalah Rosul dan penerima wahyu langsung dari Allah sehingga kebenaran tafsirnya tidak diragukan. Tapi sayangnya beliau telah meninggal sehingga pada abad-abad sesudahnya, para Ulama' berpendapat bahwa setiaporang berhak menafsirkan ayat-ayat Al-Qur'an selama mereka memiliki syarat-syarat tertentu seperti pengetahuan tentang nahwu, sharraf, balagah, ilmu usuluddin, ilmu qira'ah,asbabun Nuzul, nasikh mansukh dan lain sebagainya. ${ }^{42}$

Terkait denagn kewarisan, status orang murtad disamakan dengan orang kafir yang berarti mempunyai kedudukan yang sama dengan orang kafir asli. Karena orang murtad tidak dapat menjadi muwaris bagi ahli warisnya yang muslim ataupun sebaliknya. Dasar hukum dalam hal ini ialah mengambil pada rujukan keumuman hadis yang di riwayatkan oleh Usamah bin Zaid. ${ }^{51}$

Ketentuan dalam Kompilasi Hukum Islam (KHI) sangat tegas bahwa hak kewarisan otomatis terputus ketika berkaitan dengan perbedaan agama.Aturan dalam KHI mendasarkan seutuhnya pada pendapat Ulama' klasik khusunya Imam Syafi'i. Bahkan dalam Surat Edaran biro Peradilan Agama tanggal 18 Februari 1958 Nomor B/I/735 hukum materil yang dijadikan pedoman dalam bidangbidang hukum Kompilasi Hukum Islam adalah bersumber pada 13 (tiga belas)

${ }^{39}$ Sulaiman Rasyid, Op-Cit, hlm. 352

${ }^{40}$ Ibid.

${ }^{41}$ Fazlur Rahman, Tema Pokok Al-Qur'an, (Pnerjemah Anas Wahyudin), (Bandung: Penerbit Pustaka, 1999), hlm 1

${ }^{42}$ M.Quraish Shihab, Membumikan al-Qur'an: Fungsi dan Peran Wahyu dalam Kehidupan Masyarakat, (Bandung: Mizan, 1994), hlm 46

${ }^{51}$ Al-Jaziri, Kitab Al-Fighi 'Ala Mazhah Al-Arba'ah, (Bairut: dar Al-Kutub, 1996), hlm 436-437 


\section{AS-SYAR'I: Jurnal Bimbingan \& Konseling Keluarga}

buah kitab yang kesemuanya merupakan madzhab syafi'i. ${ }^{69}$

Berikut adalah table rumusan tim CLD-KHI disbanding denagn rumusan $\mathrm{KHI}$ inpres terkait dengan persoalan hak kewarisan, yaitu : ${ }^{75}$

\begin{tabular}{|c|c|c|c|}
\hline No & Materi & KHI & CLD-KHI \\
\hline 1 & $\begin{array}{l}\text { Waris } \\
\text { agama }\end{array}$ & $\begin{array}{l}\text { Beda agama menjadi } \\
\text { penghalang (mani') proses } \\
\text { waris-mewarisi (Pasal } 171 \\
\text { dan 172) }\end{array}$ & $\begin{array}{l}\begin{array}{l}\text { Beda agama bukan } \\
\text { penghalang } \\
\text { proses }\end{array} \text { waris-mewarisi } \\
\text { (pasal 2) }\end{array}$ \\
\hline 2 & $\begin{array}{l}\text { Anak di luar } \\
\text { perkawinan }\end{array}$ & $\begin{array}{l}\text { Hanya memiliki hubungan } \\
\text { waris dari ibunya, } \\
\text { sekalipun } \\
\text { biologisnya } \\
\text { diketahui (Pasal 186) }\end{array}$ & $\begin{array}{l}\text { Jika diketahui ayah } \\
\text { biologisnya, anak tetap } \\
\text { memiliki hak waris dari } \\
\text { ayah } \\
\text { (Pasal 16) }\end{array}$ \\
\hline 3 & ‘Awl dan radd & $\begin{array}{l}\text { Dipakai (Pasal } 192 \text { dan } \\
\text { 193) }\end{array}$ & Dihapus \\
\hline 4 & $\begin{array}{l}\text { Pembagian waris } \\
\text { bagi anak laki- } \\
\text { laki } \\
\text { perempuan }\end{array}$ & $\begin{array}{l}\text { Bagian anak laki-laki dan } \\
\text { perempuan adalah } 2: 1\end{array}$ & $\begin{array}{lll}\text { Proporsinya } & \text { sama, } & 1: 1 \\
\text { atau } & & 2: 2 \\
\text { (Pasal 8 [3]) } & & \end{array}$ \\
\hline
\end{tabular}

\section{KESIMPULAN}

Berdasarkan pembahasan pada bab sebelumnya, maka penulis dapat menarik kesimpulan sebagai berikut:

1. Kedudukan anak non muslim terhadap harta warisan pewaris Islam berdasarkan hukum Islam tidak mendapatkan harta warisan dari harta peninggalan orang tuanya yang beragama Islam setelah kedua orang tuanya meninggal dunia.

2. Menurut Kompilasi Hukum Islam sebagaimana pada kasus Pengadilan Agama menunjukkan bahwa kedudukan anak non Islam terhadap harta warisan dari peninggalan harta kedua orang tuanya yang beragama Islam tidak mendapatkan warisan sebagainya mestinya baik non muslim karena murtad maupun non muslim karena status kafir, namun berdasarkan Pengadilan Tinggi Agama mendapatkan bagian yang disebut dengan "Wasiat Wajibah".

\section{SARAN}

Selanjutnya penulis memberikan beberapa saran-saran yang dianggap penting,

${ }^{69}$ Soesilo dan Pramudji (Penerjemah), Kitab Undang-Undang Hukum Perdata (burgelijk Wetboek), (Rhedbook Publisher, Tanpa Tahun), hlm 552

${ }^{75} \mathrm{Ibid}$, hIm 50 


\section{AS-SYAR'I: Jurnal Bimbingan \& Konseling Keluarga}

sebagaimana berikut :

1. Hukum Islam adalah ketetapan hukum yang harus ditaati, oleh karena itu hendaknya ketentuan yang telah ditetapkan berdasarkan hukum Islam terhadap pembagian harta warisan dijalankan sepenuhnya sehingga hukum Islam benarbenar ditegakkan. Bila terjadi kasus gugatan terhadap pembagian harta warisan, hendaknya Pengadilan agama dapat objektif melihat kasus atau kedudukan yang sebenarnya terhadap pembagian harta warisan apabila sebelumnya belum dibagi.

2. Terhadap anak non muslim di lingkungan keluarga Islam merupakan suatu keharusan untuk menerima keputusan ketentuan hukum Islam terhadap kedudukannya dalam harta warisan dari keluarganya yang beragama Islam, oleh karena itu hendaknya dapat difahami. Bagi anak non muslim baik karena murtad maupun kafir hendaklah tidak menuntut agar mendapatkan hak terhadap harta warisan peninggalan orang tuanya yang muslim, karena dalam hukum Islam kedudukan anak non muslim tidak mendapat harta warisan dari peninggalan harta orang tuanya.

\section{DAFTAR PUSTAKA}

Abdullah Ahmed An-Na'im, 1990. Dekonstruksi Syari'ah: Wacaa Kebebasan Sipil, HAM dan Hubungan International Dalam Islam, Yogyakarta; LKIS.

Ahmad Rafiq., 1995. Hukum Islam Di Indonesia, PT. Raja Grafindo Persada, Jakarta. 1998. Hukum Islam Di Indonesia, PT. Raja Grafindo Persada, Jakarta

Ahmed An-Na'im, 1993. Al-Qur'an, Syari'ah dan HAM: Kini dan Masa Depan, Islamika No.2, 1993

Al-Jassas, 1993. Ahkam Al-qur'an, Bairut: Dar Fikr

Al-Jaziri, 1996. Kitab Al-Fiqhi 'Ala Mazhah Al-Arba'ah, Bairut: dar Al-Kutub, hlm 436437

Al-Qurtubi. 1985. Al-Jami' Lil Ahkam Al-Qur'an, III: 34, dan Al-Kaya Al-Harasi, Ahkam Al-Qur'an, (Bairut: Dar Al-Kutub Al-Imamiyah.

Al-Zarqani, Syrah Az-Zarqani Tanpa tahun. 'Ala Syrah Muwatta Al-Imam Malik, (Bairut: darul Fikr, Tanpa Tahun), III.

Asy-Syafi'ie. 1933. Al-Umm, Mesir: Al-Azhar

Asgar, Ali Engineer, 1993. Islam dan Pembebasan, Yogyakarta: LKIS dan Pustaka Pelajar).

1999. Islam dan Teologi Pembahasan, (Penerjemah Agung Prihantoro), (Yogyakarta: Pustaka Pelajar, 1999)

Asgar Ali Engineer. Tanpa tahun. Metodologi Memahami Al-Qur'an, dalam Apa Kabar Islam?

Rekonstruksi Pemikiran Al-Qur'an, dalam Apa Kabar Islam, Alih Bahasa Forstudia, Belum Diterbitkan, Yogyakarta 


\section{AS-SYAR'I: Jurnal Bimbingan \& Konseling Keluarga}

Badrul Aini. Tanpa tahun. Syarah Shahih Bukhari. Mesir: Abdus Salam

Budiarto, 2001. Harta Warisan Pewaris Islam non Muslim. Jakarta: Rineka Cipta, Jakarta Cawidu, 1991. Konsep Kufr dalam Al-Qur'an, Jakarta: Bulan Bintang,

Departemen Agama RI, 1996. Al-Qur'an dan Terjemahannya. Jakarta: Bumi Restu

Fahtcur Raman. 1994, Ilmu Waris, Bandung: PT. Al Ma'aruf

Farid Mas'udi, 1993. Agama Keadilan: Risalah Zakat (Pajak) Dalam Islam, Jakarta; Pustaka Firdaus

Hamka, T1983. afsir Al-Azbar, Jakarta: Pustaka Panjimas

Hazirin., 1982. Hukum Kekeluargaan Nasional, Jakarta: Tinta Mas.

Ibnu Hazm, 1970. Al-Muhalla, Bairut: Dar Al-Fikr

Ibnu Qudamah, Tanpa tahun. Al-Muqni, (Mesir: Matba'ah Jumhuriyah Islamiyah, VI: 130-301

Imam An-Nawawi, Tanpa tahin. Faid Al-Bari Mukhtasyar Syah Al-Bukhury, (TTp: AlMaktabah At-Tijriah.

Kadir Audah, Tanpa tahun. At-Tasyri' Al-Jina'I Al-Islam, I: 534, Muhammad Abu Zahrah, Al-Jarimah Wa Al-Uqubah Fi Al-Alifiqh al-Islami, Bairut: Darul Fikr.

M. Agus Nuryanto, 2001. Islam, Teologi Pembebasan dan Kesetaraan Gender, Studi atas Pemikiran Asgar Ali Engineer, (Yogyakarta: UII Press,

M. Idris Ramulyo. 1994. Perbandingan Pelaksanaan Hukum Kewarisan Islam Dengan Kewarisan Menurut Hukum Perdata, Jakarta: Sinar Grafika.

M. Khalid Mas'ud, 1995. Filsafat Hukum Islam dan Perubahan Sosial, Surabaya: AlIkhlas

M. Munir, 1992.Kompilasi Hukum Islam Di Indonesia, Bandung: Humaniora.

Marzuki Wahid, 2008. Counter Legal Draft Kompilasi Islam (CLD-KHI) Dalam Perspektif Politik hukum Di Indonesia, makalah dalam The $4^{\text {th }}$ Annual Islamic Studies Postgraduate Conference, The University of Melbourne, 17-18 November 2008

Masjfuk Zuhdi, 1996. Masail Fiqhiyah (Kapita Selekta Hukum Islam), Jakarta: PT. Gunung Agung,

Muhammad Ali Ash Shabuniy., 1991. Hukum Waris Islam, Jakarta: Al-Ikhlas.

Muhammad Jawad Mugniyah, 1996. Fiqh Lima Madzhah, (Penerjemah MAsykur A.B), Jakarta: Lentera.

Muslich Maruzi., 1991. Pokok-Pokok Ilmu Waris., Pustaka Amani, Jakarta

Quraish Shihab, 994. Membumikan al-Qur'an: Fungsi dan Peran Wahyu dalam Kehidupan Masyarakat, Bandung: Mizan.

Rahman, 1999. Tema Pokok Al-Qur'an, (Pnerjemah Anas Wahyudin), Bandung: Penerbit Pustaka

Sayuti Thalib., 1993. H.ukum Kewarisan Islam Di Indonesia, Sinar Grafika, Jakarta, 1993 Soesilo dan Pramudji (Penerjemah), Tanpa tahun. Kitab Undang-Undang Hukum Perdata (burgelijk Wetboek), New York: Rhedbook Publisher

Suhrawardi K Lubis. 1995. Hukum Waris Islam, Sinar Grafika, Jakarta, 1995

Sulaiman Rasyid, 2007. Fiqh Islam,Sinar Baru, Jakarta 


\section{AS-SYAR'I: Jurnal Bimbingan \& Konseling Keluarga}

Wahbah Az-Zuhaili, 1989. Al-Fiqh Al-Islam wa Adillatuhu, (Bairut: Dar Al-Fikri Al-Mu'sir,

Wirjono Projodikoro, 1980. Hukum Waris di Indonesia, Sumur, Bandung. 